\title{
Invasive crayfish and crayfish plague on the move: first detection of the plague agent Aphanomyces astaci in the Romanian Danube
}

\author{
Lucian Pârvulescu $^{1, *}$, Anne Schrimpi ${ }^{2}$, Eva Kozubíková $^{3}$, Sara Cabanillas Resino ${ }^{3}$, \\ Trude Vrålstad ${ }^{4,5}$, Adam Petrusek ${ }^{3, * *}$, Ralf Schulz ${ }^{2, * *}$
}

${ }^{1}$ West University of Timisoara, Faculty of Chemistry, Biology, Geography, Dept. of Biology and Chemistry, 300115 Timisoara, Romania

${ }^{2}$ University Koblenz-Landau, Institute for Environmental Sciences, 76829 Landau, Germany

${ }^{3}$ Charles University in Prague, Faculty of Science, Department of Ecology, 12844 Prague 2, Czech Republic

${ }^{4}$ Norwegian Veterinary Institute, Section of Mycology, 0033 Oslo, Norway

${ }^{5}$ University of Oslo, Department of Biology, 0316 Oslo, Norway

\begin{abstract}
Native European crayfish, such as Astacus leptodactylus, are threatened, among other factors, by the crayfish plague agent Aphanomyces astaci, dispersed by invasive North American crayfish. Two of these invaders, Pacifastacus leniusculus and Orconectes limosus, have extended their distribution in the River Danube catchment; the latter was detected for the first time in Romania in 2008. We monitored, at monthly intervals for over $2 \mathrm{yr}$, occurrence of native $A$. leptodactylus and invasive O. limosus at 6 sites on the Romanian Danube and checked for the invasive species in 4 of its tributaries. Between January 2009 and March 2011, the relative abundances of $O$. limosus steadily increased with time, while the native A. leptodactylus dramatically decreased in abundance. $O$. limosus expanded downstream at a rate of ca. $15 \mathrm{~km} \mathrm{yr}^{-1}$; in August 2011, it was already present in the upper $105 \mathrm{~km}$ of the Romanian Danube. An agent-specific realtime PCR analyses demonstrated the presence of A. astaci DNA in at least $32 \%$ of the analysed invasive ( $\mathrm{n}=71)$ and $41 \%$ of the native $(\mathrm{n}=49)$ crayfish coexisting in the Danube. Furthermore, A. astaci was also detected in A. leptodactylus captured about $70 \mathrm{~km}$ downstream of the $O$. limosus invasion front (at the time of sampling). Assuming a steady rate of expansion, O. limosus may invade the sensitive Danube delta area in the mid-2060s, even without long-distance dispersal. The crayfish plague agent, however, may reach the delta substantially earlier, through dispersal downstream among populations of native crayfish.
\end{abstract}

KEY WORDS: Crayfish plague $\cdot$ Aphanomyces astaci $\cdot$ Quantitative real-time PCR $\cdot$ Molecular diagnostics · Danube · Non-indigenous crayfish - Orconectes limosus - Indigenous crayfish · Astacus leptodactylus

\section{INTRODUCTION}

Crayfish plague is a crayfish-specific disease caused by the oomycete Aphanomyces astaci, an obligate parasite of freshwater crayfish (Söderhäll \& Cerenius 1999). While all European crayfish species are highly susceptible, infection does not usually cause disease outbreaks or death in North American crayfish species (OIE 2009) unless they are stressed (Persson \& Söderhäll 1983, Cerenius et al. 1988) or exposed to extremely high concentrations of shortlived A. astaci zoospores (Diéguez-Uribeondo \& 
Söderhäll 1993). It is assumed that A. astaci does not usually survive for more than a few weeks without a crayfish host (Söderhäll \& Cerenius 1999, CEFAS 2000), and no durable stages (oospores) are known in the parasite's life cycle.

All 3 of the North American crayfish species most widely distributed in Europe - the spiny-cheek crayfish Orconectes limosus (introduced in 1890), the signal crayfish Pacifastacus leniusculus, and the red swamp crayfish Procambarus clarkii (both introduced in the 1950-60s) - act as carriers of the crayfish plague pathogen (e.g. Vey et al. 1983). They are, therefore, regional reservoirs of the disease in invaded areas and contribute to its further dispersion into areas dominated by native European crayfish species. However, the disease itself had already started to spread across the continent by the 1860s and 1870s (Alderman 1996), before the first documented introductions of American crayfish species. There were repeated disease outbreaks in the late nineteenth and early twentieth centuries across a substantial part of the continent, leading to a sharp decline in native crayfish species. Regions affected by the disease were most of Central and Eastern Europe (including western Russia, Belarus, Ukraine, and the lower Danube basin), southern Fennoscandia, and parts of Western Europe, particularly Germany and the eastern half of France (Alderman 1996). Most European regions not impacted by this particular major wave of crayfish plague outbreaks became affected later in the twentieth century, after intensive introductions of $P$. leniusculus and $P$. clarkii (e.g. Alderman et al. 1990, Taugbøl et al. 1993, Diéguez-Uribeondo 2006). Due to its virulence and devastating impact on indigenous European crayfish species, Aphanomyces astaci has been classified among the world's 100 worst invasive alien species (Lowe et al. 2004).

The only non-indigenous crayfish species in Romania, Orconectes limosus, was detected in the Romanian Danube for the first time in 2008 (Pârvulescu et al. 2009), having reached the area by downstream dispersal through the Danube. The species itself has been present in Europe since 1890, apparently due to a single successful introduction (Filipová et al. 2011). However, it did not colonise the Danube until 1985, when a wild population became established in Hungary (Puky \& Schád 2006), from where it dispersed both upstream (e.g. Puky 2009) and downstream. Its downstream colonisation rate over 20 yr has been estimated at 13 to $16 \mathrm{~km} \mathrm{yr}^{-1}$ (Puky \& Schád 2006). O. limosus has also entered Croatia through the Danube from Hungary; it has entered the River Drava and is spreading upstream at a rate of $\sim 1.5 \mathrm{~km} \mathrm{yr}^{-1}$, affecting native populations of Astacus leptodactylus (Maguire \& Klobučar 2003, Faller et al. 2009).

The presence of Orconectes limosus in Romania may dramatically affect populations of the indigenous narrow-clawed crayfish Astacus leptodactylus, which occurs both in the Danube itself and in other watercourses of the catchment (Băcescu 1967). Furthermore, the indigenous stone crayfish Austropotamobius torrentium is common in most tributaries of the Romanian Danube (Pârvulescu \& Petrescu 2010). These areas are also of crucial importance from a conservation perspective. Besides carrying Aphanomyces astaci, other characteristics of O. limosus, such as high fecundity and early maturation time, contribute to its negative pressure on native crayfish populations (Hamr 2002, Kozák et al. 2006, 2007, Schulz et al. 2006). Furthermore, a recently demonstrated potential for facultative parthenogenesis in this species (Buřič et al. 2011) may also contribute to its invasive potential.

The first outbreak of the crayfish plague in the upper Danube basin was registered in Bavaria, Germany, in early 1879; following this the outbreaks quickly (within a few months) spread to upper Austria and further downstream (Alderman 1996). In less than 1 decade, the disease had spread as far as the Black Sea. Recently, crayfish plague outbreaks in the Danube catchment were reported from the Czech Republic (Kozubíková \& Petrusek 2009) and Austria (Hochwimmer et al. 2009), and populations of OrConectes limosus in the Hungarian Danube have been confirmed to carry the crayfish plague pathogen (Kozubíková et al. 2010). Although Romania must have been substantially affected by outbreaks of this disease in the late nineteenth century (Alderman 1996), there are only a very few later reports of crayfish mass mortalities (for example, of native noble crayfish Astacus astacus in 1934-1935 in the Olt River, a tributary of the Danube; Băcescu 1967). However, their association with crayfish plague has never been definitively proven. During the last several years, molecular diagnostic tools employing conventional PCR and real-time PCR methods for the specific detection of Aphanomyces astaci have been developed, and these have accelerated and improved the detection and identification of the crayfish plague agent (Oidtmann et al. 2006, Hochwimmer et al. 2009, Vrålstad et al. 2009). The carrier status of symptom-free North American crayfish is also evaluated using these tools (Oidtmann et al. 2006, Kozubíková et al. 2009, 2011b, Vrålstad et al. 2009, 2011, Skov et al. 2011). 
Reliable information on the presence of the crayfish plague agent in the Romanian Danube and on the level of threat posed to native crayfish by the quickly spreading Orconectes limosus is of key importance for freshwater management and species conservation actions. In this study, we monitored the distribution dynamics of $O$. limosus and Astacus leptodactylus in the upper Romanian Danube and its tributaries and analysed their carrier status using the most sensitive and reliable molecular diagnostic assays available. We employed the TaqMan ${ }^{\circledR}$ minor groove binder (MGB) real-time PCR (Vrålstad et al. 2009). Recent results show that this method offers higher sensitivity than any other presently available, and it is the preferred method for screening populations of North American crayfish for carrier status (Tuffs \& Oidtmann 2011). Furthermore, this method leads to lower error rates in the detection of Aphanomyces astaci than alternatives based on conventional PCR (Kozubíková et al. 2011b).

\section{MATERIALS AND METHODS}

\section{Crayfish monitoring}

Six sites along the eastern section of the Romanian Danube, each covering $5 \mathrm{~km}$ of the river's shore stretch, were surveyed monthly, using the same capture effort, from January 2009 to March 2011 in order to estimate relative crayfish abundances. One surveyed site was the location of a well-known Orconectes limosus invasion, near the village of Coronini (CO in Fig. 1); and another site further downstream near the village of Berzasca (BE) had more recent evidence of invasion (Pârvulescu et al. 2009). In order to estimate the actual invasion front at Svinița (SV) properly, the investigated stretch of the river was twice as long $(10 \mathrm{~km})$ as for the other sites. Three sites downstream of the suspected invasion area were investigated: Dubova (DU), Ieșelnița (IE) and Drobeta-Turnu Severin (SE). The downstream distance to each subsequent sampling site was approximately $15 \mathrm{~km}$ (Fig. 1).

Crayfish were captured using 2 bottom fishing nets of $1.5 \mathrm{~m}$ height, $25 \mathrm{~m}$ width, and a mesh size of ca. $30 \mathrm{~mm}$, baited with fish meat and checked twice a week for a total period of $2 \mathrm{wk}$ in each month. After capture, the species and sex of each individual was determined. Four Danube tributaries, Cameniţa River (R1 in Fig. 1), Radimna River (R2), Gornea River (R3) and Berzasca River (R4), were investigated using hand sampling of the riverbed during the sum- mer of 2010 to assess whether Orconectes limosus shows a tendency to move upstream and colonise smaller watercourses. These tributaries are known to be populated by the stone crayfish Austropotamobius torrentium in areas between 1 to $10 \mathrm{~km}$ upstream of the confluence with the Danube (Pârvulescu \& Petrescu 2010).

\section{Molecular diagnostics}

Crayfish were sacrificed at random to determine the presence of Aphanomyces astaci in both species by freezing them in separate plastic bags at $-10^{\circ} \mathrm{C}$. Altogether, we analysed 71 individuals of Orconectes limosus and 49 of Astacus leptodactylus. The crayfish were divided and analysed separately in 3 laboratories (in Oslo, Norway; Landau, Germany; and Prague, Czech Republic). For 42 crayfish (41 O. limosus and 1 A. leptodactylus) analysed in Prague, $50 \mathrm{mg}$ of crayfish tissue, including the soft ventral abdominal cuticle and a part of the tail fan (uropods and/or telson), was dissected and processed according to the methodology described in Kozubíková et al. (2009). For the remaining 78 crayfish analysed in the laboratories at Oslo and Landau (30 O. limosus and $48 \mathrm{~A}$. leptodactylus), 4 different tissue segments were dissected following methodology used by Vrålstad et al. (2011) and were preserved in 96\% ethanol. The tissues included (1) the soft ventral abdominal cuticle; (2) the tail fan; (3) the inner joints of 2 walking legs; and (4) black spots (if present) on the exoskeleton. The melanised spots can be caused by an immune reaction against pathogens (including $A$. astaci) and may therefore indicate infection (Cerenius et al. 2003). The dissection tools were thoroughly disinfected after handling each individual crayfish.

DNA from the dissected tissues was extracted according to either Vrålstad et al. (2009; for the analyses in Oslo and Landau) or Kozubíková et al. (2009; for the analyses in Prague). An environmental control $(200 \mu$ l nuclease-free milliQ water in a tube, left open during the DNA extraction procedure) and an extraction blank control were included in the subsequent real-time PCR analyses as recommended by Vrålstad et al. (2009).

A quantitative TaqMan ${ }^{\circledR}$ MGB real-time PCR (Vrålstad et al. 2009) was conducted independently in all 3 laboratories to verify the presence of Aphanomyces astaci. This method is based on the detection of a 59 bp long A. astaci-specific fragment of the most variable part of the internal transcribed spacer region (ITS1) of the nuclear rDNA. Real-time 


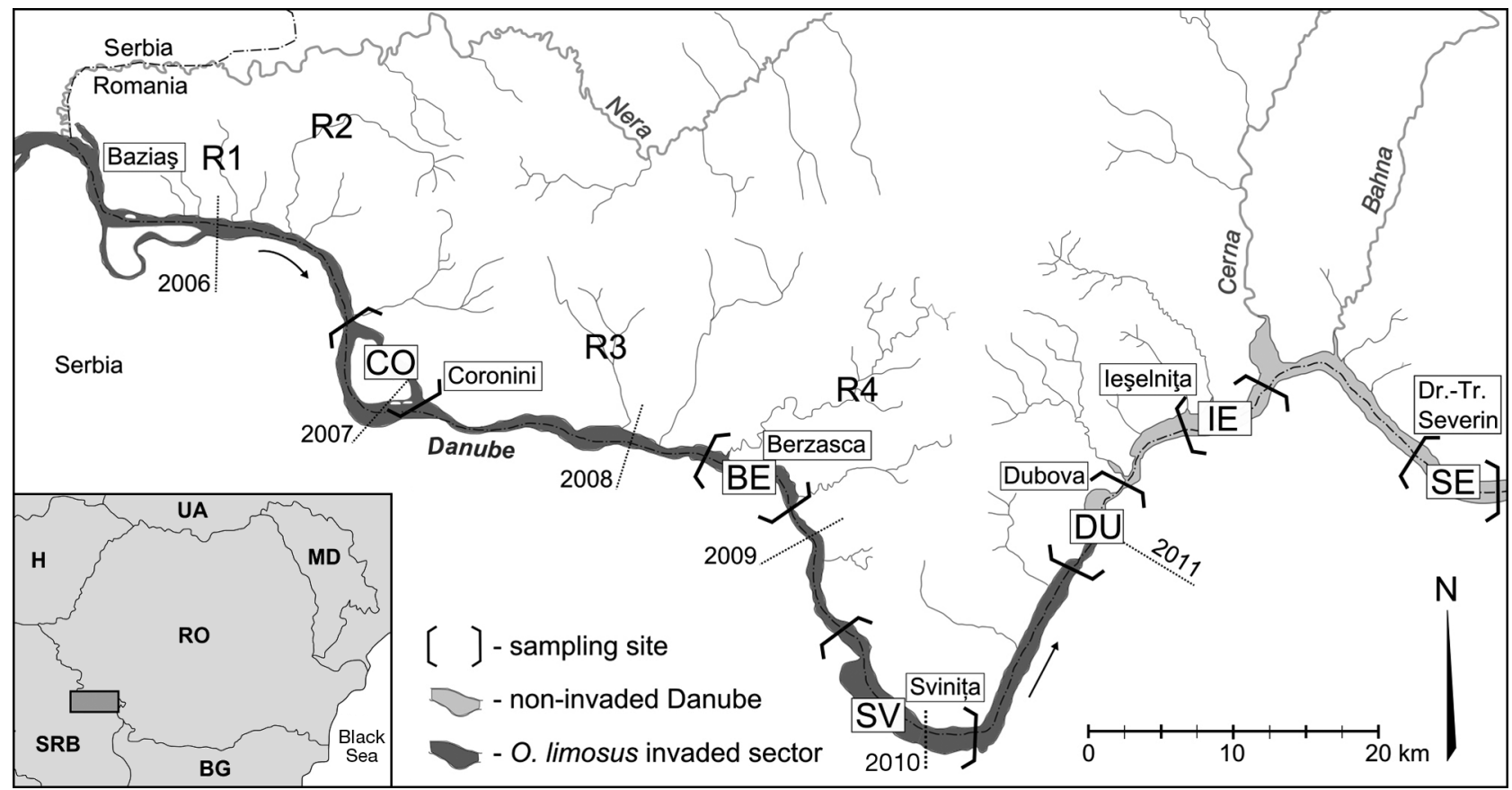

Fig. 1. Sampling sites in the River Danube (CO, BE, SV, DU, IE, SE) and its tributaries (R1 to R4; for river names see 'Materials and methods') in Romania and Serbia. Estimated years indicating the rate of invasion of this species are provided; Orconetes limosus was recorded at the DU site in August 2011. Dr.-Tr. Severin: Droberta-Turnu Severin. International license plate codes used for countries in inset map

PCR reactions were performed on a Mx3005P qPCR system (Stratagene) or on a Mastercycler ${ }^{\circledR}$ ep realplex S (Eppendorf) according to Strand et al. (2011), using the TaqMan ${ }^{\circledR}$ Environmental Master Mix to avoid PCR inhibition (Strand et al. 2011), and on an iQ5 Real-Time PCR Detection System (Bio-Rad) using the Universal PCR Master Mix (Life Technologies) according to Vrålstad et al. (2009). Data analysis was carried out using MxPro software version 4.10 (Stratagene), Real Plex 2.2 (Eppendorf), and iQ5 Optical System Software (Bio-Rad), respectively. A 4-fold dilution series of genomic DNA from a pure $A$. astaci culture (starting concentration: $5 \mathrm{ng}^{-1} \mathrm{l}^{-1}$ served both as a standard and positive control. Unknown samples were included as concentrated $(1 \times)$ and $5 \times$ diluted templates for the Stratagene and Eppendorf PCR setup, whilst concentrated $(1 \times)$ and $10 \times$ diluted templates were analysed on the Bio-Rad system. Different dilutions, used to check for potential PCR-inhibition, were used to comply with standard protocols that had been established in the different laboratories.

The agent prevalence was quantified based on PCR-forming units (PFU), according to the methodology used by Vrålstad et al. (2009), in which 1 PFU corresponds to 1 amplifiable target DNA copy. Each sample was also assigned to semi-quantitative agent levels. Samples for which a weak signal below the limit of detection (= $5 \mathrm{PFU}$ ) was observed were considered negative (Vrålstad et al. 2009). Absolute quantification is possible in the absence of PCR inhibition above the limit of quantification (LOQ = 50 PFU according to Vrålstad et al. 2009). Possible real-time PCR inhibition was checked for by comparison of results obtained from concentrated and diluted samples. In the absence of inhibition, with an acceptance of $15 \%$ variation, the difference in cycle threshold $\left(C_{\mathrm{t}}\right)$ values should be $2.32 \pm 0.35$ and $3.32 \pm 0.48$ for the 5 and $10 \times$ dilutions, respectively, when compared to undiluted DNA, (see Kozubíková et al. 2011b for more details). However, as many samples, particularly from Orconectes limosus, yielded results below LOQ, a quantitative comparison could not be made. Thus, we used a 1-tailed nonparametric Wilcoxon matched pairs test to evaluate whether the undiluted samples yielded significantly higher levels of agent DNA, which would at least imply that most samples were not substantially affected by inhibition.

The identity of Aphanomyces astaci was further confirmed by amplifying and sequencing a $529 \mathrm{bp}$ long ITS fragment (including ITS1 as well as ITS2) 
from 6 DNA isolates representing both host crayfish species, according to protocol used by Oidtmann et al. (2006), with primers 42 and 640 designed to be specific for A. astaci (but see Kozubíková et al. 2011b for discussion on their limitation). The PCR products were sequenced in the forward direction using the primer 42, and resulting sequences (GenBank accession numbers JN713915-JN713917) were aligned in Mega 5 (Tamura et al. 2011) together with those representing all presently known $A$. astaci genotype groups (As, PsI, PsII, Pc, Or) isolated from various crayfish hosts: Astacus astacus, Pacifastacus leniusculus, Procambarus clarkii, as well as Orconectes limosus (see Kozubíková et al. 2011a). The alignment was then checked visually for the presence of differences among sequences.

\section{RESULTS}

\section{Occurrence and dynamics of Orconectes limosus and Astacus leptodactylus}

The front of the downstream invasion of the River Danube by Orconectes limosus was, by the end of the regular monitoring (March 2011), found to be near Svinița, $998 \mathrm{~km}$ upstream from the Black Sea (Fig. 1). The species was first detected at this site in May 2010, when only the upper $5 \mathrm{~km}$ stretch of Site SV contained O. limosus, whereas no individuals of the invasive species were captured in the downstream $5 \mathrm{~km}$ stretch. During the $2 \mathrm{yr}$ duration of the regular monitoring, O. limosus moved down the River Danube by about $21 \mathrm{~km}$ from below Site BE to Site SV (Fig. 1). However, the most recent investigation, in August 2011, has confirmed the species at Dubova (Site DU), $25 \mathrm{~km}$ further downstream of Svinița.

Altogether, 2068 individuals of Orconectes limosus and 4552 of Astacus leptodactylus were captured during the survey period (January 2009 to March 2011). The 3 downstream sites in the River Danube (DU, IE, and SE) contained only A. leptodactylus, of which 3006 specimens were collected during the present study. A comparison of the relative abundances of both crayfish species at the upper 3 sampling sites along the Danube $(\mathrm{CO}, \mathrm{BE}$, and SV) shows a very large decline in the native species A. leptodactylus at Site BE, at which the relative abundance of the invasive species was about $75 \%$ (Fig. 2). The relative abundance of $O$. limosus at the invasion front (SV) in early 2011 was about $7.2 \%$ (Fig. 2). The sex ratio of $O$. limosus var- ied among sites: the percentage of captured males was $60.1 \%$ at $\mathrm{CO}$, and decreased further downstream to $59.4 \%$ at $\mathrm{BE}$ and $47.1 \%$ at $\mathrm{SV}$.

The crayfish monitoring results differed between tributaries, depending mainly on the width of the tributary. In the small tributaries, Cameniţa, Radimna and Gornea (R1 to R3 in Fig. 1), each of which is less than $3 \mathrm{~m}$ wide at the confluence with the Danube, the invasive species was only found directly at the confluence, and only extended for some tens of metres upstream. In the Berzasca tributary (R4), with a mean width of about $7 \mathrm{~m}$ at the confluence, the invasive species was found up to $1400 \mathrm{~m}$ upstream of the tributary mouth. This was despite the fact that the time available for colonising this tributary was much shorter than for the tributaries R1 to R3 situated further upstream along the Danube. During the investigation period, a total of 161 individuals of Orconectes limosus were captured in the Berzasca. The distance separating the invasive species and the native Austropotamobius torrentium populations in the tributaries was $1050 \mathrm{~m}$ at Cameniţa, $3200 \mathrm{~m}$ at Radimna, $4550 \mathrm{~m}$ at Gornea and $10800 \mathrm{~m}$ at Berzasca.

\section{Molecular detection of Aphanomyces astaci}

The crayfish plague agent Aphanomyces astaci was detected in $32 \%$ of the investigated Orconectes limosus specimens collected from Sites CO and BE (Table 1). PFU values in undiluted DNA samples from $A$. astaci-positive individuals ranged between 5 and approximately 27000 , corresponding to agent levels from A2 to A5 (Table 2), according to Vrålstad et al. (2009). Most of these samples were found to contain a low amount of the target DNA (Levels A2 and A3), and only one showed a high agent level (A5). Furthermore, A. astaci was also detected in 20 of the 49 investigated Astacus leptodactylus specimens (Table 2), even though their general state and behaviour did not indicate acute crayfish plague. Most importantly, we also detected $A$. astaci in 3 individuals of A. leptodactylus from Site SE, situated $68 \mathrm{~km}$ downstream of the $O$. limosus invasion front known at the time of sampling. All 6 ITS sequences obtained from isolates from $5 \mathrm{O}$. limosus from both Sites $\mathrm{CO}$ and $\mathrm{BE}$, and 1 A. leptodactylus from $\mathrm{BE}$, were invariant. They corresponded exactly to sequences from $A$. astaci strains of all 5 known genotype groups of the pathogen, including the 


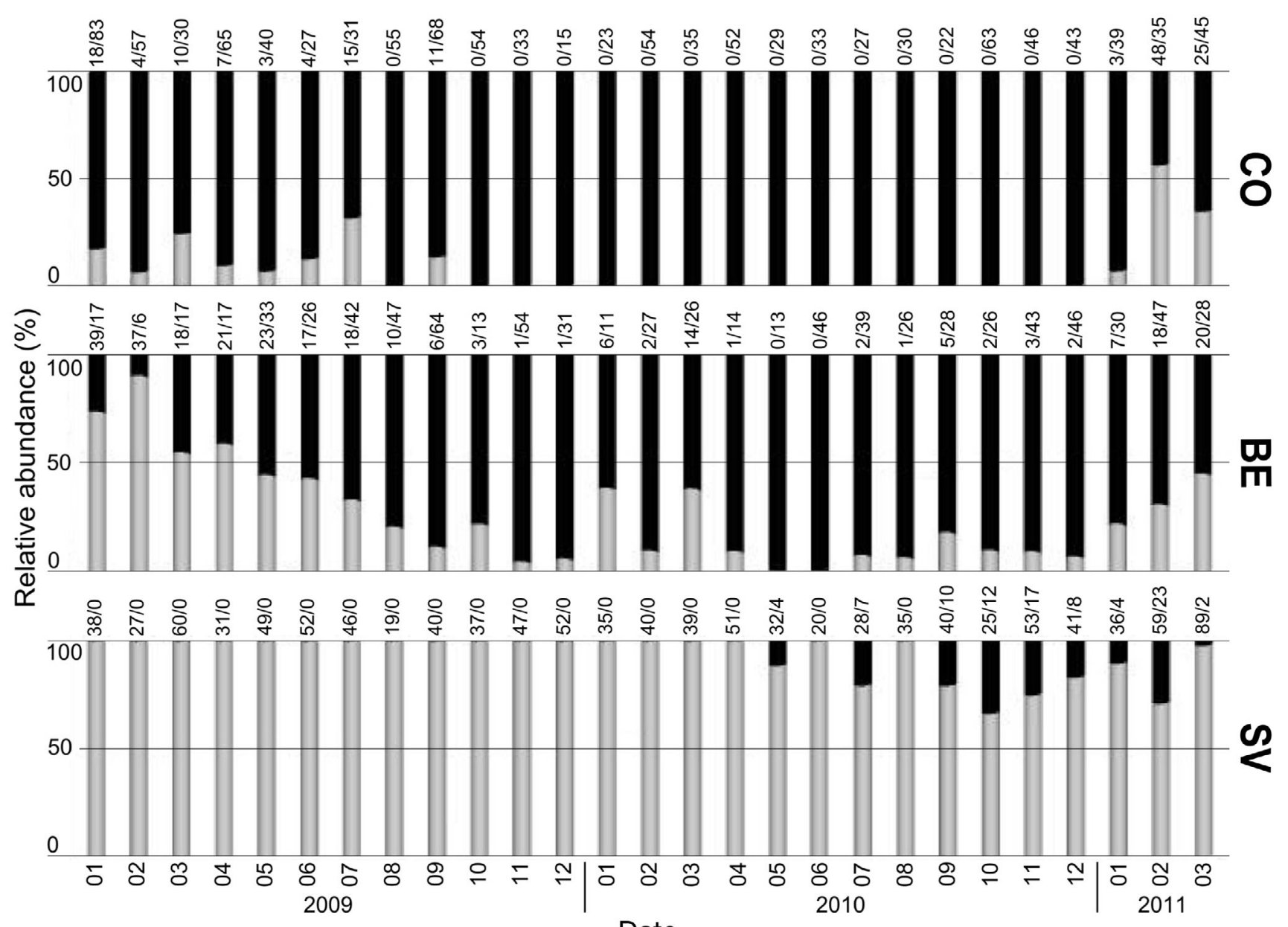

Date

Fig. 2. Astacus leptodactylus and Orconectes limosus. Relative abundance of native A. leptodactylus (grey bars) and invasive O. limosus (black bars) at 3 sites of the River Danube (see Fig. 1) over a period of 27 mo. Upper graph: CO (Coronini); middle graph: BE (Berzasca); lower graph: SV (Sviniţa; invasion front). Numbers above the bars refer to the absolute total number of A. leptodactylus and $O$. limosus, respectively, caught during each sampling period

one obtained from $O$. limosus (Kozubíková et al. 2011a). The sequencing thus corroborated the results of the real-time PCR analysis.

Significantly higher levels of Aphanomyces astaci DNA were found in samples of undiluted template DNA in the PCR setup, in comparison to $5 \times$ diluted template samples using Environmental Master Mix (1-tailed Wilcoxon matched pairs test, $\mathrm{n}=31, Z=$ $2.86, \mathrm{p}=0.002$ ) as well as when compared to $10 \times$ diluted samples using Universal PCR Master Mix ( $\mathrm{n}=$ $9 ; Z=2.67 ; \mathrm{p}=0.004)$. However, for 1 Astacus leptodactylus and 2 Orconectes limosus individuals, A. astaci was detected in diluted samples only. This suggests that although inhibition was not a major problem, it occasionally affected the efficiency of detection, potentially underestimating the extent of infection.

\section{DISCUSSION}

Our study clearly showed that Orconectes limosus is rapidly spreading downstream in the Romanian stretch of the Danube, and that its populations are infected by the crayfish plague pathogen Aphanomyces astaci. We also demonstrated that $A$. astaci had been transferred to local populations of the native narrow-clawed crayfish Astacus leptodactylus, which strongly declined in coexistence with $O$. limosus. Furthermore, the pathogen was detected in an A. leptodactylus population well in advance of the main invasion front of the invasive species. The rate of $O$. limosus invasion in the Romanian Danube identified by our study was comparable to other studies quantifying its dispersal in this river. Given that in January 2009 O. limosus was found in the Berzasca 
Table 1. Aphanomyces astaci infecting Astacus leptodactylus and Orconectes limosus. Number of crayfish from the Romanian Danube analysed for A. astaci infection using real-time PCR and percentage of specimens detected positive

\begin{tabular}{|llccc|}
\hline Sampling site & Species & $\begin{array}{c}\text { No. of crayfish } \\
\text { analysed }\end{array}$ & $\begin{array}{c}\text { A. astaci- } \\
\text { positive }\end{array}$ & \% infected \\
\hline Coronini (CO) & A. leptodactylus & 1 & 1 & 100 \\
& O. limosus & 37 & 9 & 24 \\
Berzasca (BE) & A. leptodactylus & 24 & 6 & 25 \\
& O. limosus & 34 & 14 & 41 \\
Svinița (SV) & A. leptodactylus & 21 & 10 & 48 \\
Severin (SE) & A. leptodactylus & 3 & 3 & 100 \\
Total & A. leptodactylus & 49 & 20 & 41 \\
& O. limosus & 71 & 23 & 32 \\
\hline
\end{tabular}

Table 2. Aphanomyces astaci infecting Astacus leptodactylus and Orconectes limosus. Summary data on the real-time PCR detection of A. astaci from native and invasive crayfish from 4 sites on the River Danube (see Fig. 1). Agent levels refer to semi-quantitative categories based on the observed numbers of PCR-forming units ( $\mathrm{PFU}_{\mathrm{obs}}$ ), according to Vrålstad et al. (2009). Agent Level 0 $\left(\mathrm{A}_{0}\right.$; no detection) and Agent Level $1\left(\mathrm{~A}_{1}\right.$; detection below the limit of detection: $\left.\mathrm{PFU}_{\text {obs }}<5 \mathrm{PFU}\right)$ are both considered negative. Remaining categories $\left(\mathrm{A}_{2}\right.$ to $\mathrm{A}_{5}$ ) are considered as a positive detection of the pathogen. $\mathrm{A}_{2}: 5 \mathrm{PFU} \leq$ $\mathrm{PFU}_{\text {obs }}<50$ PFU; $\mathrm{A}_{3}: 50 \mathrm{PFU} \leq \mathrm{PFU}_{\text {obs }}<10^{3} \mathrm{PFU}_{;} \mathrm{A}_{4}: 10^{3} \mathrm{PFU} \leq \mathrm{PFU}_{\text {obs }}<$ $10^{4} \mathrm{PFU} ; \mathrm{A}_{5}: 10^{4} \mathrm{PFU} \leq \mathrm{PFU}_{\text {obs }}<10^{5} \mathrm{PFU}$

\begin{tabular}{|c|c|c|c|c|c|c|c|c|}
\hline \multirow[t]{2}{*}{ Sampling site } & \multirow[t]{2}{*}{ Species } & \multirow{2}{*}{$\begin{array}{l}\text { No. of crayfish } \\
\text { analysed }\end{array}$} & \multicolumn{6}{|c|}{ Agent level } \\
\hline & & & $\mathrm{A}_{0}$ & $\mathrm{~A}_{1}$ & $\mathrm{~A}_{2}$ & $\mathrm{~A}_{3}$ & $\mathrm{~A}_{4}$ & $\mathrm{~A}_{5}$ \\
\hline \multirow[t]{2}{*}{ Coronini (CO) } & A. leptodactylus & 1 & & & & & & 1 \\
\hline & O. limosus & 37 & 21 & 7 & 4 & 4 & & 1 \\
\hline \multirow[t]{2}{*}{ Berzasca (BE) } & A. leptodactylus & 24 & 18 & & 2 & 3 & & 1 \\
\hline & O. limosus & 34 & 13 & 7 & 10 & 4 & & \\
\hline Svinița (SV) & A. leptodactylus & 21 & 11 & & 5 & 2 & 3 & \\
\hline Severin (SE) & A. leptodactylus & 3 & & & & 3 & & \\
\hline
\end{tabular}

and a slow displacement of the native species due to the competitive advantages of the invader has been observed for mixed populations of Orconectes limosus and Astacus astacus in which the pathogen was not detected (Schulz et al. 2006) and also for coexisting $A$. astacus and presumably non-infected Pacifastacus leniusculus (Westman et al. 2002). When Aphanomyces astaci is present, however, a fast elimination of whole populations of European native crayfish can be expected (Westman et al. 2002).

Our confirmation of the causative agent of the crayfish plague in the Romanian Danube highlights the threat that the presence of Orconectes limosus poses to the indigenous crayfish populations (Longshaw 2011). We confirmed that substantial proportions of $O$. limosus carry the crayfish plague pathogen in both stretches of the Danube we investigated, where the species is already well established (CO and BE). Since the abundance of $O$. limosus is still low at the present invasion front, no conclusions can yet be made on the presence of Aphanomyces astaci for this site. However, we provided real-time PCR-based evidence for the presence of $A$. astaci in native Astacus leptodactylus (with

region (Site $\mathrm{BE} ; 1015 \mathrm{~km}$ before the Danube flows into the Black Sea), and reached Svinița by May 2010 (Site SE; $998 \mathrm{~km}$ upstream of the Black Sea), the estimated average colonisation speed is $1.23 \mathrm{~km} \mathrm{mo}^{-1}$, or about $15 \mathrm{~km} \mathrm{yr}^{-1}$, consistent with the findings of other studies (Puky \& Schád 2006, Hudina et al. 2009). In August 2011 the species reached Dubova (DU), having moved $25 \mathrm{~km}$ downstream of Svinița, at a rate of $1.56 \mathrm{~km} \mathrm{mo}^{-1}$, slightly above the average calculated colonisation speed.

The serious decline in the relative abundance of the indigenous species Astacus leptodactylus in the Coronini area (CO), and the decrease in its relative abundance in the Berzasca area (BE), suggests that the invasive species has a tendency to eliminate the indigenous populations. The population dynamics of native European crayfish susceptible to crayfish plague that are in contact with invasive crayfish populations is, amongst other aspects, strongly dependent on the presence of the pathogen. For example, coexistence melanised spots on the exoskeleton) about $70 \mathrm{~km}$ below the suspected invasion front of $O$. limosus at the time of sampling. Although we cannot rule out that some infected $O$. limosus could have dispersed substantially farther than suggested by our monitoring data, it is likely that $A$. astaci is spreading downstream ahead of the invasive crayfish, by gradual expansion through local A. leptodactylus populations. Multiple mechanisms may contribute to the pathogen dispersal, apart from movement activity of crayfish. These include, for example, passive transport of infected live or dead crayfish (or even their exuviae). Furthermore, a direct dispersal of zoospores carried for a short distance by river currents may also be a source of infection for populations of A. leptodactylus further downstream. Due to these mechanisms, $A$. astaci may move down the River Danube much faster than the invasion front of $O$. limosus.

Dispersal of the crayfish plague through a river with abundant populations of susceptible crayfish 
may be very fast, as demonstrated by the rate at which the Danube catchment was affected during the major outbreak of crayfish plague in the 1870s-1890s (Alderman 1996). It is, therefore, possible that the pathogen will reach the Danube delta within a few years. On the other hand, if the rate of expansion of Orconectes limosus does not change substantially, the invasive crayfish itself may reach the Danube delta in the mid-2060s. However, anthropogenic long-range dispersal (for example, by shipping) may speed up its invasion considerably. The importance of invasive crayfish for introduction and dispersal of Aphanomyces astaci has also recently been reported for Procambarus clarkii in Italy (Aquiloni et al. 2011).

In crayfish populations sensitive to crayfish plague, the pathogen prevalence usually gradually increases over time, mostly reaching $100 \%$ (OIE 2009). This typically results in complete elimination of populations impacted by the plague, including stream populations of Austropotamobius torrentium (e.g. Kozubíková et al. 2008). However, some evidence exists that Astacus leptodactylus is at least sometimes more resistant to infection than other European species (Unestam 1969) and may be able to coexist with Aphanomyces astaci for extended periods of time. This has been implied particularly for some Turkish lakes where the pathogen has been assumed to be present continuously for over 2 decades, despite the absence of American crayfish species in the country (Harlioğlu 2008). Recent molecular analyses of material from one of these Turkish lakes (Svoboda et al. 2012) confirmed that $A$. astaci may indeed persist in a population of $A$. leptodactylus that retains sufficient density for commercially harvesting. It is, therefore, possible that $A$. leptodactylus populations in the Danube will not be completely eliminated after introduction of $A$. astaci but will rather serve, at least temporarily, as a potential source of its further dispersal. This is also supported by our finding of A. leptodactylus in winter 2011 at Site CO, in which Orconectes limosus, and supposedly also A. astaci, had been present for about 4 yr (Fig. 2).

The facts that not only American but also native species of crayfish may serve as the source of crayfish plague infection and that not all North American crayfish are carriers of the pathogen, together with observed coexistence between European and North American crayfish species (Nylund \& Westman 1992, Westman et al. 2002, Hudina et al. 2009, Skov et al. 2011), highlight the importance of using reliable detection methods for testing for presence of Aphanomyces astaci in suspected host populations. In the present study, we successfully applied MGB realtime PCR as proposed by Vrålstad et al. (2009) and Strand et al. (2011) to evaluate infection status independently in 3 laboratories and used ITS sequencing as an independent verification of the crayfish plague agent $A$. astaci.

We mostly found relatively low PFU values and corresponding very low (A2) and low (A3) agent levels (according to Vrålstad et al. 2009) but, nevertheless, unambiguously confirmed the presence of $A$. astaci in both invasive Orconectes limosus and native Astacus leptodactylus. Our results suggest that PCR inhibition was unlikely a major problem in our analyses. Nonetheless, the proportion of infected individuals might be underestimated, as we could not analyse the whole crayfish body for A. astaci presence, and detections of trace amounts of pathogen DNA (under $5 \mathrm{PFU}$ ) were considered negative to avoid potential false positives.

The results of monitoring of Danube tributaries confirmed the observations of Petrusek et al. (2006) from the Elbe catchment, where Orconectes limosus rarely penetrates far into low-order watercourses unless aided by humans. However, the risk of the crayfish plague agent expanding to native crayfish populations in small streams cannot be ignored, even in the absence of any direct encounters with $O$. limosus, mainly because uncontrolled fishing takes place regularly in this area. Aphanomyces astaci can be transferred from one water body to the next through fishing gear, contaminated traps, the transfer of infected animals, and probably even by predators preying on crayfish (Nylund \& Westman 1992, Alderman 1996, Oidtmann et al. 2002). It has been estimated that if the European-wide distribution and abundance of native stocks continue to decline and invasive crayfish species continue rapid expansion at the present rates, all European watersheds suitable for crayfish might be inhabited by invasive species within 100 yr (Skurdal \& Taugbøl 2002, Holdich et al. 2009). The example of Sweden, where only around $5 \%$ of the native crayfish populations remain since the introduction of the crayfish plague (Fjälling \& Fürst 1988, Bohman et al. 2006), shows the need for increased conservation effort to protect native species as soon as the plague agent enters a country.

Since invasive crayfish are not as widespread in Romania as in most other European countries, Romanian conservation managers have the opportunity to learn from the experience of other countries and act before it is too late. Based on our data, we assume the crayfish plague agent may reach the Danube delta very soon, and no measures can stop or slow it down. Protection 
of Romanian native crayfish populations may be made more efficient in preservation of Astacus astacus and Austropotamobius torrentium by identifying or artificially establishing so-called 'ark-sites' (Peay 2009a). Detailed investigations, and a well-organised management plan based on sound research findings, are strongly recommended, but additional conservation measures including education of local stakeholders and communities, fishermen, and children (Peay 2009b) are needed as well. This is particularly relevant in this region, where fishing is a major occupation, and simple and inexpensive measures (such as avoidance of using the same fishing tools in other rivers as in the Danube) may prevent the disease spreading from the Danube into the tributaries.

Acknowledgements. We thank the following for the approval of our study: the Romanian Academy (2257/CJ/2009), Iron Gates (Por ile de Fier) Natural Park Administration (136/2010; 3847/2011), the Environmental Protection Agency, CaraşSeverin County (423/2010; 1884/2011), and Mehedinţi County (1404/2010; 2785/2011). Some of the analyses were funded by the Czech Ministry of Education (project no. MSM0021620828), the Grant Agency of the Charles University (154110), and the Czech Science Foundation (206/08/ H049). The field investigations were supported by the BioTeam Association (Timisoara, Romania). We thank Cristian Paloş, Daniel Vuia, Amelia Ţundrea, and Dorin Ianoş for help with the fieldwork, and David Strand for assistance in the laboratory. Three anonymous reviewers provided useful comments on a previous version of the manuscript.

\section{LITERATURE CITED}

Alderman DJ (1996) Geographical spread of bacterial and fungal diseases of crustaceans. Rev Sci Tech Off Int Epizoot 15:603-632

Alderman DJ, Holdich D, Reeve I (1990) Signal crayfish as vectors in crayfish plague in Britain. Aquaculture 86:3-6

Aquiloni L, Martin MP, Gherardi F, Diéguez-Uribeondo J (2011) The north American crayfish Procambarus clarkii is the carrier of the oomycete Aphanomyces astaci in Italy. Biol Invasions 13:359-367

Băcescu MC (1967) Fauna Republicii Socialiste România, Vol 4. Crustacea: Decapoda (The fauna of Romanian Socialist Republic, Vol 4. Crustacea, Decapoda). Academic Publishing House, Bucharest (in Romanian)

Bohman P, Nordwall F, Edsman L (2006) The effect of the large-scale introduction of signal crayfish on the spread of crayfish plague in Sweden. Bull Fr Peche Piscicult 380-381:1291-1302

Buřič M, Hulák M, Kouba A, Petrusek A, Kozák P (2011) A successful crayfish invader is capable of facultative parthenogenesis: a novel reproductive mode in decapod crustaceans. PLoS ONE 6:e20281

CEFAS (Centre for Environment Fisheries and Aquaculture Science) (2000) Summary final report: effects of exposure to high and low temperatures on the survival of the crayfish plague fungus $A$. astaci in vitro and in vivo. Australian Quarantine and Inspection Service, Canberra

Cerenius L, Söderhäll K, Persson M, Axajon R (1988) The crayfish plague fungus Aphanomyces astaci diagnosis, isolation, and pathobiology. Freshw Crayfish 7:131-144 Cerenius L, Bangyeekhun E, Keyser P, Söderhäll I, Söderhäll K (2003) Host prophenoloxidase expression in freshwater crayfish is linked to increased resistance to the crayfish plague fungus, Aphanomyces astaci. Cell Microbiol 5:353-357

Diéguez-Uribeondo J (2006) Pathogens, parasites and ectocommensals. In: Souty-Grosset C, Holdich DM, Noël PY, Reynolds JD, Haffner P (eds) Atlas of crayfish in Europe. Patrimoines Naturels 64, Muséum National d'Histoire Naturelle, Paris, p 131-149

> Diéguez-Uribeondo J, Söderhäll K (1993) Procambarus clarkii Girard as a vector for the crayfish plague fungus, Aphanomyces astaci Schikora. Aquacult Res 24:761-765

Faller M, Hudina S, Klobučar G, Maguire I (2009). Spread of invasive spiny-cheek crayfish (Orconectes limosus) in Croatia: filling knowledge gaps and identifying confinement measures. In: Kozák P, Kouba A (eds) Abstract book. Future of native crayfish in Europe. Regional European Crayfish Workshop: 7th-10th September 2009, Písek. Research Institute of Fish Cultures and Hydrobiology, Vodňany

Filipová L, Lieb DA, Grandjean F, Petrusek A (2011) Haplotype variation in the spiny-cheek crayfish Orconectes limosus: colonization of Europe and genetic diversity of native stocks. J N Am Benthol Soc 30:871-881

Fjälling A, Fürst M (1988) The development of a fishery for the crayfish Pacifastacus leniusculus in Sweden 1960-86. Freshw Crayfish 7:223-230

Hamr P (2002) Orconectes. In: Holdich DM (ed) Biology of freshwater crayfish. Blackwell Science, Oxford, p 585-608

Harlioğlu MM (2008) The harvest of the freshwater crayfish Astacus leptodactylus Eschscholtz in Turkey: harvest history, impact of crayfish plague, and present distribution of harvested populations. Aquacult Int 16:351-360

> Hochwimmer G, Tober R, Bibars-Reiter R, Licek E, Steinborn R (2009) Identification of two GH18 chitinase family genes and their use as targets for detection of the crayfish-plague oomycete Aphanomyces astaci. BMC Microbiol 9:184

> Holdich DM, Reynolds JD, Souty-Grosset C, Sibley PJ (2009) A review of the ever increasing threat to European crayfish from non-indigenous crayfish species. Knowl Manag Aquat Ecosyst 394-395:11

Hudina S, Faller M, Lucić A, Klobučar G, Maguire I (2009) Distribution and dispersal of two invasive crayfish species in the Drava River basin, Croatia. Knowl Manag Aquat Ecosyst 394-395:9

Kozák P, Buřič M, Policar T (2006) The fecundity, time of egg development and juvenile production in spiny-cheek crayfish (Orconectes limosus) under controlled conditions. Bull Fr Peche Piscicult 380-381:1171-1182

> Kozák P, Hulák M, Policar T, Tichý F (2007) Studies of annual gonadal development and gonadal ultrastructure in spiny-cheek crayfish (Orconectes limosus). Bull Fr Peche Piscicult 384:15-26

Kozubíková E, Petrusek A (2009) Račí mor - přehled dosavadních poznatků o závažném onemocnění raků a zhodnocení situace v České republice. (Crayfish plague - review of present knowledge on serious disease of crayfish and evaluation of the situation in the Czech Republic). Bull VÚRH Vodňany 45:34-57 (in Czech with English summary) 
Kozubíková E, Petrusek A, Ďuriš Z, Martín MP, DiéguezUribeondo J, Oidtmann B (2008) The old menace is back: recent crayfish plague outbreaks in the Czech Republic. Aquaculture 274:208-217

Kozubíková E, Filipová L, Kozák P, Ďuriš Z and others (2009) Prevalence of the crayfish plague pathogen Aphanomy ces astaci in invasive American crayfishes in the Czech Republic. Conserv Biol 23:1204-1213

Kozubíková E, Puky M, Kiszely P, Petrusek A (2010) Crayfish plague pathogen in invasive North American crayfish species in Hungary. J Fish Dis 33:925-929

Kozubíková E, Viljamaa-Dirks S, Heinikainen S, Petrusek A (2011a) Spiny-cheek crayfish Orconectes limosus carry a novel genotype of the crayfish plague agent Aphanomyces astaci. J Invertebr Pathol 108:214-216

Kozubíková E, Vrålstad T, Filipová L, Petrusek A (2011b) Re-examination of the prevalence of Aphanomyces astaci in North American crayfish populations in Central Europe by TaqMan MGB real-time PCR. Dis Aquat Org 97:113-125

Longshaw M (2011) Diseases of crayfish: a review. J Invertebr Pathol 106:54-70

Lowe S, Browne M, Boudjelas S, De Poorter M (2004) 100 of the world's worst invasive alien species. A selection from the Global Invasive Species Database, the Invasive Species Specialist Group (ISSG), a specialist group of the Species Survival Commission (SSC) of the IUCN. IUCN, Gland

Maguire I, Klobučar G (2003) Appearance of Orconectes limosus in Croatia. Crayfish News. IAA Newsl 25:7

Nylund V, Westman K (1992) Crayfish diseases and their control in Finland. Report from the EIFAC workshop on crayfish management and stocking, 22-23 August 1991, Kuopio, Finland. Finn Fish Res 14:107-118

Oidtmann B, Heitz E, Rogers D, Hoffmann RW (2002) Transmission of crayfish plague. Dis Aquat Org 52:159-167

Oidtmann B, Geiger S, Steinbauer P, Culas A, Hoffmann RW (2006) Detection of Aphanomyces astaci in North American crayfish by polymerase chain reaction. Dis Aquat Org 72:53-64

OIE (Office international des épizooties) (2009) Crayfish plague (Aphanomyces astaci). Chapter 2.2.1. In: Manual of diagnostic tests for aquatic animals, 6th edition. Office international des épizooties, Paris, p 63-77. Available at: www.oie.int (accessed 1 April 2011)

Pârvulescu L, Paloş C, Molnar P (2009) First record of the spiny-cheek crayfish Orconectes limosus (Rafinesque, 1817) (Crustacea: Decapoda: Cambaridae) in Romania. North-West J Zool 5:424-428

Pârvulescu L, Petrescu I (2010) The distribution of stone crayfish Austropotamobius torrentium (Schrank, 1803) (Crustacea: Decapoda: Astacidae) in the south-west Romanian mountain and sub-mountain area. Trav Mus Natl Hist Nat 'Grigore Antipa' 53:103-113

Peay S (2009a) Selection criteria for 'ark sites' for whiteclawed crayfish. In: Brickland J, Holdich DM, Imhoff EM (eds) Crayfish conservation in the British Isles. Proceedings of conference held in Leeds, p 63-69. Available at: http://iz.carnegiemnh.org/crayfish/IAA/docs/2009_Cray fish_Conservation_in_the_British_Isles_LR.pdf

Peay S (2009b) Invasive non-indigenous crayfish species in Europe: recommendations on managing them. Knowl Manag Aquat Ecosyst 394-395:9

Persson M, Söderhäll K (1983) Pacifastacus leniusculus Dana and its resistance to the parasitic fungus Aphano- myces astaci Schikora. Freshw Crayfish 5:292-298

> Petrusek A, Filipová L, Ďuriš Z, Horká I and others (2006) Distribution of the invasive spiny-cheek crayfish (Orconectes limosus) in the Czech Republic. Past and present. Bull Fr Peche Piscicult 380-381:903-917

Puky M (2009) Confirmation of the presence of the spinycheek crayfish Orconectes limosus (Rafinesque, 1817) (Crustacea: Decapoda: Cambaridae) in Slovakia. NorthWest J Zool 5:214-217

> Puky M, Schád P (2006) Orconectes limosus colonises new areas fast along the Danube in Hungary. Bull Fr Peche Piscicult 380-381:919-926

Schulz HK, Smietana P, Maiwald T, Oidtmann B, Schulz R (2006) Case studies on the co-occurrence of Astacus astacus (L.) and Orconectes limosus (Raf.): snapshots of a slow displacement. Freshw Crayfish 15:212-219

> Skov C, Aarestrup K, Sivebæk F, Pedersen S, Vrålstad T, Berg S (2011) Non-indigenous signal crayfish (Pacifastacus leniusculus) are now common in Danish streams: preliminary status for national distribution and protective actions. Biol Invasions 13:1269-1274

Skurdal J, Taugbøl T (2002) Astacus. In: Holdich DM (ed) Biology of freshwater crayfish. Blackwell Science, Oxford, p 467-510

Söderhäll K, Cerenius L (1999) The crayfish plague fungus: history and recent advances. Freshw Crayfish 12:11-35

> Strand DA, Holst-Jensen A, Viljugrein H, Edvardsen B, Klaveness D, Jussila J, Vrålstad T (2011) Detection and quantification of the crayfish plague agent in natural waters: direct monitoring approach for aquatic environments. Dis Aquat Org 95:9-17

Svoboda J, Kozubíková E, Kozák P, Kouba A and others (2012) PCR detection of the crayfish plague pathogen in narrow-clawed crayfish inhabiting Lake Eğirdir in Turkey. Dis Aquat Org (in press)

Tamura K, Peterson D, Peterson N, Stecher G, Nei M, Kumar S (2011) MEGA5: molecular evolutionary genetics analysis using maximum likelihood, evolutionary distance, and maximum parsimony methods. Mol Biol Evol 28: 2731-2739

Taugbøl T, Skurdal J, Håstein T (1993) Crayfish plague and management strategies in Norway. Biol Conserv 63: $75-82$

Tuffs S, Oidtmann B (2011) A comparative study of molecular diagnostic methods designed to detect the crayfish plague pathogen, Aphanomyces astaci. Vet Microbiol 153:343-353

Unestam T (1969) Resistance to the crayfish plague in some American, Japanese and European crayfishes. Rep Inst Freshw Res Drottningholm 49:202-209

Vey A, Söderhall K, Ajaxon R (1983) Susceptibility of Orconectes limosus Raff to the crayfish plague, Aphanomyces astaci Schikora. Freshw Crayfish 2:284-291

Vrålstad T, Knutsen AK, Tengs T, Holst-Jensen A (2009) A quantitative TaqMan (R) MGB real-time polymerase chain reaction based assay for detection of the causative agent of crayfish plague Aphanomyces astaci. Vet Microbiol 137:146-155

Vrålstad T, Johnsen SI, Fristad RF, Edsman L, Strand D (2011) Potent infection reservoir of crayfish plague now permanently established in Norway. Dis Aquat Org 97:75-83

Westman K, Savolainen R, Julkunen M (2002) Replacement of the native crayfish Astacus astacus by the introduced species Pacifastacus leniusculus in a small, enclosed Finnish lake: a 30-year study. Ecography 25:53-73 